\title{
Article \\ Physiological Characterization of Sulfolobus acidocaldarius in a Controlled Bioreactor Environment
}

\author{
Kerstin Rastädter (D), David Johannes Wurm (D), Oliver Spadiut (D) and Julian Quehenberger *(D) \\ Research Division Biochemical Engineering, Faculty of Technical Chemistry, Institute of Chemical, Environmental \\ and Bioscience Engineering, TU Wien, 1060 Vienna, Austria; kerstin.rastaedter@tuwien.ac.at (K.R.); \\ david.wurm@tuwien.ac.at (D.J.W.); oliver.spadiut@tuwien.ac.at (O.S.) \\ * Correspondence: julian.quehenberger@tuwien.ac.at
}

Citation: Rastädter, K.; Wurm, D.J · Spadiut, O.; Quehenberger, J. Physiological Characterization of Sulfolobus acidocaldarius in a Controlled Bioreactor Environment. Int. J. Environ. Res. Public Health 2021, 18, 5532. https://doi.org/10.3390/ ijerph18115532

Academic Editor: Paul B. Tchounwou

Received: 18 April 2021

Accepted: 19 May 2021

Published: 21 May 2021

Publisher's Note: MDPI stays neutral with regard to jurisdictional claims in published maps and institutional affiliations.

Copyright: (C) 2021 by the authors Licensee MDPI, Basel, Switzerland. This article is an open access article distributed under the terms and conditions of the Creative Commons Attribution (CC BY) license (https:/ creativecommons.org/licenses/by/ $4.0 /)$.

\begin{abstract}
The crenarchaeal model organism Sulfolobus acidocaldarius is typically cultivated in shake flasks. Although shake flasks represent the state-of-the-art for the cultivation of this microorganism, in these systems crucial process parameters, like $\mathrm{pH}$ or substrate availability, are only set initially, but cannot be controlled during the cultivation process. As a result, a thorough characterization of growth parameters under controlled conditions is still missing for S. acidocaldarius. In this study, we conducted chemostat cultivations at $75{ }^{\circ} \mathrm{C}$ using a growth medium containing L-glutamate and D-glucose as main carbon sources. Different $\mathrm{pH}$ values and dilution rates were applied with the goal to physiologically characterize the organism in a controlled bioreactor environment. Under these controlled conditions a $\mathrm{pH}$ optimum of 3.0 was determined. Washout of the cells occurred at a dilution rate of $0.097 \mathrm{~h}^{-1}$ and the optimal productivity of biomass was observed at a dilution rate of $0.062 \mathrm{~h}^{-1}$. While both carbon sources were taken up by $S$. acidocaldarius concomitantly, a 6.6-fold higher affinity for L-glutamate was shown. When exposed to suboptimal growth conditions, $S$. acidocaldarius reacted with a change in the respiratory behavior and an increased trehalose production rate in addition to a decreased growth rate.
\end{abstract}

Keywords: Sulfolobus acidocaldarius; characterization; chemostat; dilution rate; substrate affinity; trehalose

\section{Introduction}

The extremophile Sulfolobus acidocaldarius is a widely used model organism of the phylum Crenarchaeota. Its genome sequence is available [1] and a powerful genetic tool box for investigating and engineering gene functions has been developed [2] and is continuously being improved [3]. The organism thrives in a temperature range of 65 to $85^{\circ} \mathrm{C}$ and at a $\mathrm{pH}$ ranging from $\mathrm{pH} 2.0$ to 5.5 [4], while under laboratory conditions it is generally cultivated at temperatures of 70 to $75^{\circ} \mathrm{C}$ and at a pH of 2.25 to 3.5 [5-10]. Most research with this organism is performed in batch cultivations using shake flasks as culture vessels $[5,7,11]$. However, a continuous cultivation in a stirred-tank reactor (CSTR) with the possibility to monitor and control $\mathrm{pH}$, temperature and dissolved oxygen content $\left(\mathrm{dO}_{2}\right)$ is the basis for stable growth conditions, thereby allowing the acquisition of reliable and reproducible process data [12]. Furthermore, providing the substrate in limiting amounts might also represent conditions that resembles the natural habitat of most microorganism more closely than the nutrient enriched system of batch cultivations [13-15]. In chemostat cultures the growth rate, biomass, substrate and product concentration remain constant after reaching steady state [16], thus making it a reliable tool for strain characterization as shown for a variety of microorganisms [17-19]. Critical parameters for bioprocess development, such as the optimal and critical dilution rate, affinity constants for substrates as well as maintenance coefficient, can be readily determined in a CSTR. All these parameters are missing in the current literature of Sulfolobales. 
In a CSTR a potent technique to assess the physiological condition of an organism is the monitoring of the respiratory behavior, expressed as the respiratory quotient (RQ). The RQ is the molar ratio of produced $\mathrm{CO}_{2}$ to consumed $\mathrm{O}_{2}$ and depends on the state of oxidation of the metabolized substrate and the utilized catabolic pathways [20]. Higher RQs than the theoretical value for complete oxidation of the respective substrates imply incomplete substrate utilization and potential waste of energy, while lower RQs can signify a change in the carbon flow towards metabolites and hint towards a less efficient utilization of $\mathrm{O}_{2}$. A further way to monitor metabolic stress is the direct measurement of metabolites in the culture supernatant. S. acidocaldarius produces the non-reducing disaccharide trehalose, a compound that can be found in all three domains of life, where it functions as a general protecting agent against unfavorable environmental conditions [21].

In this study, the strain S. acidocaldarius DSM639 was grown in continuous cultivation on a medium containing L-glutamate and D-glucose as main carbon sources and was physiologically characterized regarding its $\mathrm{pH}$ optimum, maximum growth rate, specific substrate uptake rates and its stress response indicated by trehalose production and respiratory behavior.

\section{Materials and Methods}

\subsection{Bioreactor Cultivations}

S. acidocaldarius DSM639, obtained at German Collection of Microorganisms and Cell Cultures (DSMZ, Braunschweig, Germany), was continuously cultivated in a DASbox Mini Bioreactor System (Eppendorf AG, Hamburg, Germany) with a working volume of $200 \mathrm{~mL}$ per vessel. Four parallel bioreactors, filled with Vienna Defined (VD) Medium [22] with modified carbon source concentrations ( $2 \mathrm{~g} / \mathrm{L}$ monosodium glutamate (MSG), $1 \mathrm{~g} / \mathrm{L}$ D-glucose) were inoculated with a starting $\mathrm{OD}_{600}$ of 0.17 , yielding a total batch volume of $150 \mathrm{~mL}$. Feed used during fed-batch and chemostat phases contained a 5-times concentrated VD Medium with modified carbon source concentrations (9.5 g/L MSG, $4.5 \mathrm{~g} / \mathrm{L}$ D-glucose

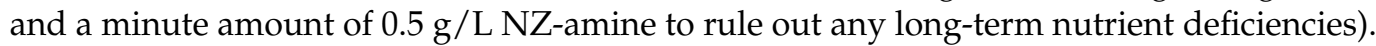
Fed-batch phase was performed with a continuous feed rate of $3.0 \mathrm{~mL} / \mathrm{h}$ until a reactor volume of $200 \mathrm{~mL}$ was reached. During the following chemostat phase, the feed rate was set to $6.0 \mathrm{~mL} / \mathrm{h}\left(D=0.03 \mathrm{~h}^{-1}\right)$. To maintain a constant volume of $200 \mathrm{~mL}$, broth was withdrawn from the reactor via a bleed tube at a fixed height. The reactors were stirred with $600 \mathrm{rpm}$ and supplied with $0.3 \mathrm{vvm}$ (volumes gas flow per working volume per minute; equal to: $3.6 \mathrm{sL} / \mathrm{h}$; liter at standardized conditions, $273.15 \mathrm{~K}$ and 1 bar per hour) pressurized air. A constant growth temperature of $75^{\circ} \mathrm{C}$ was achieved by submerging the reactor vessels in a stirred heated oil bath. $\mathrm{pH}$ was measured with an EasyFerm Plus K8 120 electrode (Hamilton, OH, USA) and was adjusted by automatic addition of $4.8 \% \mathrm{H}_{2} \mathrm{SO}_{4}$. Dissolved oxygen $\left(\mathrm{dO}_{2}\right)$ was monitored by a VisiFerm DO225 probe (Hamilton, OH, USA). $\mathrm{CO}_{2}$ and $\mathrm{O}_{2}$ concentrations were measured using the DASGIP GA4 exhaust analyzer (Eppendorf AG, Hamburg, Germany).

To assess reproducibility three bioreactors of the DASbox Mini Bioreactor System were subjected to the same conditions $\left(75^{\circ} \mathrm{C}, \mathrm{pH} 3.0, D=0.03 \mathrm{~h}^{-1}\right)$. Table 1 gives an overview of the experiments performed in this study.

Table 1. Experimental plan of this study: chemostat cultivations with a dilution rate $(D)$ of $0.03 \mathrm{~h}^{-1}$ were performed at 5 different $\mathrm{pH}$ values. The following set of experiments where the dilution rate was varied from $0.010 \mathrm{~h}^{-1}$ to $0.097 \mathrm{~h}^{-1}$ was then performed at the prior determined $\mathrm{pH}$ optimum of 3.0.

\begin{tabular}{cccc}
\hline \multicolumn{2}{c}{ Fixed Parameter } & \multicolumn{2}{c}{ Variable Parameter } \\
\hline$D$ & $0.03 \mathrm{~h}^{-1}$ & $\mathrm{pH}$ & $2.0,2.5,3.0,3.5,4.0$ \\
\hline $\mathrm{pH}$ & 3.0 & $D$ & $0.010 \mathrm{~h}^{-1}, 0.021 \mathrm{~h}^{-1}, 0.032 \mathrm{~h}^{-1}, 0.043 \mathrm{~h}^{-1}, 0.053 \mathrm{~h}^{-1}, 0.064 \mathrm{~h}^{-1}, 0.074 \mathrm{~h}^{-1}, 0.084 \mathrm{~h}^{-1}, 0.097 \mathrm{~h}^{-1}$ \\
\hline
\end{tabular}

Since the cultivation performed at pH 2.0 in the DASbox Mini Bioreactor System yielded an inexplicably high $\mathrm{CO}_{2}$ yield and consequently a C-balance that significantly 
exceeded a value of 1.0, this experiment was excluded from the study and was instead repeated in a 2 L Biostat A-plus bioreactor (Sartorius, Goettingen, Germany). The reactor was stirred at $300 \mathrm{rpm}$ and supplied with $0.23 \mathrm{vvm}(0.45 \mathrm{sL} / \mathrm{h})$ pressurized air. The $\mathrm{pH}$ was measured with an EasyFerm Plus electrode (Hamilton, OH, USA) and controlled via automatic addition of $4.8 \% \mathrm{H}_{2} \mathrm{SO}_{4} . \mathrm{CO}_{2}$ and $\mathrm{O}_{2}$ concentrations in the exhaust gas were measured using a gas analyzing unit (Müller Systems AG, Esslingen, Switzerland). The batch phase was started with $1.5 \mathrm{~L}$ and chemostat culturing was done at $2 \mathrm{~L}$ and a dilution rate of $0.03 \mathrm{~h}^{-1}$. During fed-batch an exponential feed was applied, starting with $14.8 \mathrm{~g} / \mathrm{h}$ and a growth rate of $0.035 \mathrm{~h}^{-1}$. The cultivation was controlled using the Lucullus process control system (SecureCell AG, Urdorf, Switzerland). All other process parameters were set as mentioned for the DASbox Mini Bioreactor System.

\subsection{Biomass Determination}

Optical density, $\mathrm{OD}_{600}$, was determined photometrically at $600 \mathrm{~nm}$ with a spectrophotometer against a blank of deionized water (ONDA V-10 PLUS, XS instruments, Carpi, Italy). Samples were diluted with deionized water to stay in the linear range of the photometer. Due to the low biomass concentration and low reactor volume, dry cell weight (DCW) was not determined. A previously determined correlation factor of $0.586 \mathrm{~g} / \mathrm{L}$ (see Supplementary Figure S1) between DCW concentration and $\mathrm{OD}_{600}$ was applied.

\subsection{Substrate and Metabolites Analytics}

At each sampling point, $1 \mathrm{~mL}$ of culture broth was centrifuged at 10,000 $\mathrm{g}$ for $10 \mathrm{~min}$ at $4{ }^{\circ} \mathrm{C}$. The obtained supernatant was analyzed for its substrate and metabolite composition. D-glucose and trehalose concentrations in the supernatant were determined with an Aminex HPX-87H column ( $300 \times 7.8 \mathrm{~mm}$, Bio-Rad, Hercules, CA, USA) employing an Ultimate 3000 high-performance liquid chromatography (HPLC) system (Thermo Fisher Scientific, Waltham, MA, USA). $10 \mu \mathrm{L}$ sample were analyzed at a flow rate of $0.6 \mathrm{~mL} / \mathrm{min}$ and a column temperature of $60{ }^{\circ} \mathrm{C} .4 \mathrm{mM} \mathrm{H}_{2} \mathrm{SO}_{4}$ served as mobile phase. For quantitative determination a RI detector (RefractoMax 520, Thermo Fisher Scientific, Waltham, MA, USA) and a UV detector (VH-D10-A, Thermo Fisher Scientific, Waltham, MA, USA) at $210 \mathrm{~nm}$ were used. Chromeleon 7.2.6 Chromatography Data System (Thermo Fisher Scientific, Waltham, MA, USA) was used for control and data analysis. Glutamic acid was determined via a photometric assay using a Cedex Bio HT Analyzer (Roche, Basel, Switzerland). The obtained concentration of glutamic acid was converted to the used substrate MSG by multiplication with the factor 1.15.

\subsection{Calculation of Rates, Substrate Affinity Constants and Maintenance Coefficient}

All rates, balances and yields were determined at each sampling point and then for each condition ( $\mathrm{pH}$ \& dilution rate) the mean value of the different sampling points was calculated.

Dilution rate, $D\left[\mathrm{~h}^{-1}\right]$, in the CSTR was calculated as the sum of feed and acid addition $[\mathrm{L} / \mathrm{h}]$ divided by the reactor volume $[\mathrm{L}]$.

Dwell time, $\tau[\mathrm{h}]$, is the invers value of the dilution rate.

Specific growth rate, $\mu\left[\mathrm{h}^{-1}\right]$, was determined as the difference in DCW between two sampling points divided by the average DCW between the sampling points per hour by taking into account the loss of biomass via the bleed.

$$
\mu=\frac{\Delta X+\Delta V_{\text {bleed }} * \bar{x}}{\bar{X} * \Delta t}
$$

$\Delta t[\mathrm{~h}] \quad$ time between two sampling points

$\Delta X$ [g] difference of total DCW in broth between the two sampling points

$\Delta V_{\text {bleed }}$ [L] bleed volume removed between the two sampling points

$\bar{x}[\mathrm{~g} / \mathrm{L}]$ average DCW concentration between sampling points

$\bar{X}[\mathrm{~g}]$ average biomass in broth between sampling points 
Cell productivity, biomass space time yield, $D^{*} x\left[\mathrm{~g} \mathrm{~L}^{-1} \mathrm{~h}^{-1}\right]$, was calculated as the product of DCW concentration $[\mathrm{g} / \mathrm{L}]$ and $D\left[\mathrm{~h}^{-1}\right]$.

Specific substrate uptake rates for D-glucose, $q_{G l c}\left[g_{G l c} g(X)^{-1} h^{-1}\right]$, and L-glutamate, $q_{M S G}\left[g_{\text {MSG }} \mathrm{g}(X)^{-1} \mathrm{~h}^{-1}\right.$ ] (shown as MSG per DCW per hour), were calculated for every time span between sampling points as follows:

$$
q_{S}=\frac{\Delta S_{\text {reactor }}+S_{\text {in }}-S_{\text {out }}}{\Delta t * \bar{X}}
$$

$\Delta S_{\text {reactor }}[\mathrm{g}]$ difference of amount of substrate in broth between the two sampling points

$S_{\text {in }}[\mathrm{g}]$ substrate supplied to bioreactor within the time period

$S_{\text {out }}[\mathrm{g}] \quad$ substrate discharged via the bleed within the time period

Specific production rate of extracellular trehalose $q_{\text {Tre }}\left[\mathrm{g}_{\text {Tre }} \mathrm{g}(X)^{-1} \mathrm{~h}^{-1}\right]$ was calculated according to:

$$
q_{P}=\frac{\Delta P_{\text {reactor }}+P_{\text {in }}-P_{\text {out }}}{\Delta t * \bar{X}}
$$

$\Delta P_{\text {reactor }}[\mathrm{g}]$ difference of amount of product in broth between the two sampling points

$P_{\text {in }}[\mathrm{g}]$ product supplied to bioreactor within the time period

$P_{\text {out }}[\mathrm{g}]$ product discharged via the bleed within the time period

Biomass Yield, $\mathrm{Y}_{\mathrm{X} / \mathrm{S}}[\mathrm{g}(\mathrm{X}) / \mathrm{g}(\mathrm{S})]$, was calculated as the quotient of $\mu\left[\mathrm{h}^{-1}\right]$ and $\mathrm{q}_{S}\left[\mathrm{~g}(S) \mathrm{g}(X)^{-1} \mathrm{~h}^{-1}\right]$.

$\mathrm{CO}_{2}$ yield, $\mathrm{Y}_{\mathrm{CO} 2 / \mathrm{S}}\left[\mathrm{C}-\mathrm{mol}_{\mathrm{CO} 2} / \mathrm{C}-\mathrm{mol}_{\mathrm{S}}\right]$ was calculated as the quotient of the specific $\mathrm{CO}_{2}$ evolution rate $\left[\mathrm{C}-\mathrm{mol}_{\mathrm{CO} 2} \mathrm{~g}(X)^{-1} \mathrm{~h}^{-1}\right]$ and $\mathrm{q}_{\mathrm{S}}\left[\mathrm{C}-\mathrm{mol}_{\mathrm{S}} \mathrm{g}(X)^{-1} \mathrm{~h}^{-1}\right]$.

Trehalose yield, $\mathrm{Y}_{\mathrm{Tre} / \mathrm{S}}\left[\mathrm{C}-\mathrm{mol}_{\mathrm{Tre}} / \mathrm{C}-\mathrm{mol}_{\mathrm{S}}\right]$ was calculated as the quotient of $\mathrm{q}_{\text {Tre }}\left[\mathrm{C}-\mathrm{mol}_{\text {Tre }} \mathrm{g}(X)^{-1} \mathrm{~h}^{-1}\right]$ and $\mathrm{q}_{S}\left[\mathrm{C}-\mathrm{mol}_{\mathrm{S}} \mathrm{g}(X)^{-1} \mathrm{~h}^{-1}\right.$ ].

C-balance was determined as the sum of $Y_{\mathrm{X} / \mathrm{S}}, Y_{\mathrm{CO} / \mathrm{S}}$, and $Y_{\mathrm{Tre} / \mathrm{S}}$, all in carbon-mol per carbon-mol. A C-balance close to 1.0 implies that all carbon atoms provided via substrate can be accounted for and are recovered either in the biomass $\left(Y_{X / S}\right)$, in the exhaust gas $\left(Y_{\mathrm{CO} 2 / \mathrm{S}}\right)$ or in metabolites $\left(Y_{\mathrm{Tr} / \mathrm{S}}\right)$.

Respiratory quotient, $R Q$, was calculated as the quotient of the carbon evolution rate $\left[\mathrm{mmol} \mathrm{L}^{-1} \mathrm{~h}^{-1}\right]$ and the oxygen uptake rate $\left[\mathrm{mmol} \mathrm{L}^{-1} \mathrm{~h}^{-1}\right]$. Oxygen uptake rate and $\mathrm{CO}_{2}$ evolution rate were calculated by measuring the effluent concentrations of oxygen and $\mathrm{CO}_{2}$.

Specific carbon dioxide production rate, $q_{\mathrm{CO} 2}\left[\mathrm{mmol} \mathrm{g}(X)^{-1} \mathrm{~h}^{-1}\right]$, was determined by dividing the carbon dioxide production rate by the DCW concentration.

Specific oxygen consumption rate, $q_{\mathrm{O} 2}\left[\mathrm{mmol} g(X)^{-1} \mathrm{~h}^{-1}\right]$, was determined by dividing the oxygen uptake rate by the DCW concentration.

Substrate affinity constants, $\mathrm{Ks}[\mathrm{g} / \mathrm{L}]$ for D-glucose and MSG and the maximum growth rate, $\mu_{\max }\left[\mathrm{h}^{-1}\right]$, were fitted by using the program SigmaPlot 14 (Systat Software, San Jose, CA, USA). The growth rate was plotted versus the substrate concentration in the supernatant and a Monod function (Equation (4)) was fitted accordingly. The standard errors for $\mathrm{K}_{\mathrm{S}}$ and $\mu_{\max }$ describing the quality of the fit were calculated with SigmaPlot.

$$
\mu=\mu_{\max } \frac{S}{S+K_{S}}
$$

$\mu\left[\mathrm{h}^{-1}\right]$ growth rate calculated for each applied dilution rate

$S[\mathrm{~g} / \mathrm{L}] \quad$ substrate concentration, measured in the supernatant

With the obtained $K_{S}$ values and $\mu_{\max }$ the critical dilution rate, $D_{\text {crit }}\left[\mathrm{h}^{-1}\right]$ for both D-glucose and MSG were determined according to:

$$
D_{\text {crit }}=\mu_{\max } \frac{S_{0}}{K_{s}+S_{0}}
$$

$\mu_{\max }\left[\mathrm{h}^{-1}\right]$ maximum growth rate determined via Equation (4)

$S_{0}[\mathrm{~g} / \mathrm{L}]$ substrate concentration (D-glucose or MSG) in the supplied feed 
Optimal dilution rate, $D_{\text {opt }}\left[\mathrm{h}^{-1}\right]$, for maximum cell productivity, was calculated as follows:

$$
D_{o p t}=\mu_{\max }\left(1-\sqrt{\frac{K_{s}}{K_{s}+S_{0}}}\right)
$$

To determine the specific maintenance coefficient, $m_{s}\left[g(S) g(X)^{-1} \mathrm{~h}^{-1}\right]$, Equation (7) was rearranged to Equation (8). Subsequently, the overall specific substrate uptake rate $\mathrm{q}_{S}$ $\left(\mathrm{q}_{\mathrm{Glc}}+\mathrm{q}_{\mathrm{MSG}}\right)$ was plotted against the specific growth rates resulting in a line with a slope equivalent to $1 / Y_{X / S}{ }^{*}$ and an offset equivalent to $m_{s}$.

$$
\begin{gathered}
\mu=\left(q_{S}-m_{S}\right) * Y_{X / S}^{*} \\
q_{S}=\frac{1}{Y_{X / S}^{*}} * \mu+m_{S}
\end{gathered}
$$

$\mathrm{q}_{S}\left[\mathrm{~g}(S) \mathrm{g}(X)^{-1} \mathrm{~h}^{-}\right] \quad$ specific substrate uptake rate, the sum of $\mathrm{q}_{\mathrm{Glc}}$ and $\mathrm{q}_{\mathrm{MSG}}$

$Y_{X / S}{ }^{*}[\mathrm{~g} / \mathrm{g}]$ true biomass yield, used solely for growth

Standard deviation, STD [\%], for each parameter of the reproducibility experiments was calculated as the square root of the variance divided by its mean.

\section{Results}

Reproducibility experiments, in which three reactors were subjected to the same conditions $\left(75^{\circ} \mathrm{C}, \mathrm{pH} 3.0, D=0.03 \mathrm{~h}^{-1}\right)$, showed a standard deviation (STD) $<3 \%$ for OD, $\mu$ and $\mathrm{q}_{\mathrm{MSG}}$, whereas $\mathrm{q}_{\mathrm{Glc}}$ and $\mathrm{q}_{\mathrm{Tre}}$ exhibited a STD of $<10 \%$. In the following experiments, each condition (shift of $\mathrm{pH}$ or dilution rate) was maintained for at least four theoretical dwell times. This number of dwell times, required for reaching steady state, was determined during the reproducibility studies (data not shown).

\subsection{Effect of $\mathrm{pH}$ on Strain Physiology}

Since the $\mathrm{pH}$ optimum of this organism is still disputed in literature and recently Cobban et al. [11] showed data conflicting with the broad consensus of the optimal $\mathrm{pH}$ of 3 to 3.5 [5-10], we determined the $\mathrm{pH}$ optimum by shifting the $\mathrm{pH}$ from 2.0 to 4.0 in increments of $0.5 \mathrm{pH}$ units at a constant growth temperature of $75^{\circ} \mathrm{C}$ and dilution rate of $0.03 \mathrm{~h}^{-1}$.

In our studies, highest cell densities were reached at $\mathrm{pH} 3.0$ (Figure 1). Upon reducing the $\mathrm{pH}$ to 2.5 and 2.0, the cell density decreased by $9 \%$ and $27 \%$, respectively. Increasing the $\mathrm{pH}$ to 3.5 and 4.0 resulted in a reduction of cell density by $13 \%$ and $14 \%$, respectively.

The specific glutamate uptake rate, $\mathrm{q}_{\mathrm{MSG}}$, was constant throughout the $\mathrm{pH}$ changes with only a slight, nonsignificant increase at $\mathrm{pH} 2.0$ (Figure 2). The specific glucose uptake rate, $\mathrm{q}_{\mathrm{Gl}}$, decreased considerably at $\mathrm{pH}$ 2.0. The specific production rate of trehalose, $\mathrm{q}_{\text {Tre }}$, increased when the culture was subjected to $\mathrm{pH}$ values of 3.5 and 4.0 (1.64- and 1.37-fold, respectively), implicating a metabolic shift at higher $\mathrm{pH}$ values.

The C-balance of all cultivations closed at $1.0 \pm 0.1$. Also, RQ and biomass yield remained constant throughout all investigated $\mathrm{pH}$ values (Figure 3). Solely the $\mathrm{CO}_{2}$ yield increased at $\mathrm{pH} 2.0$ compared to the other $\mathrm{pH}$ conditions. 


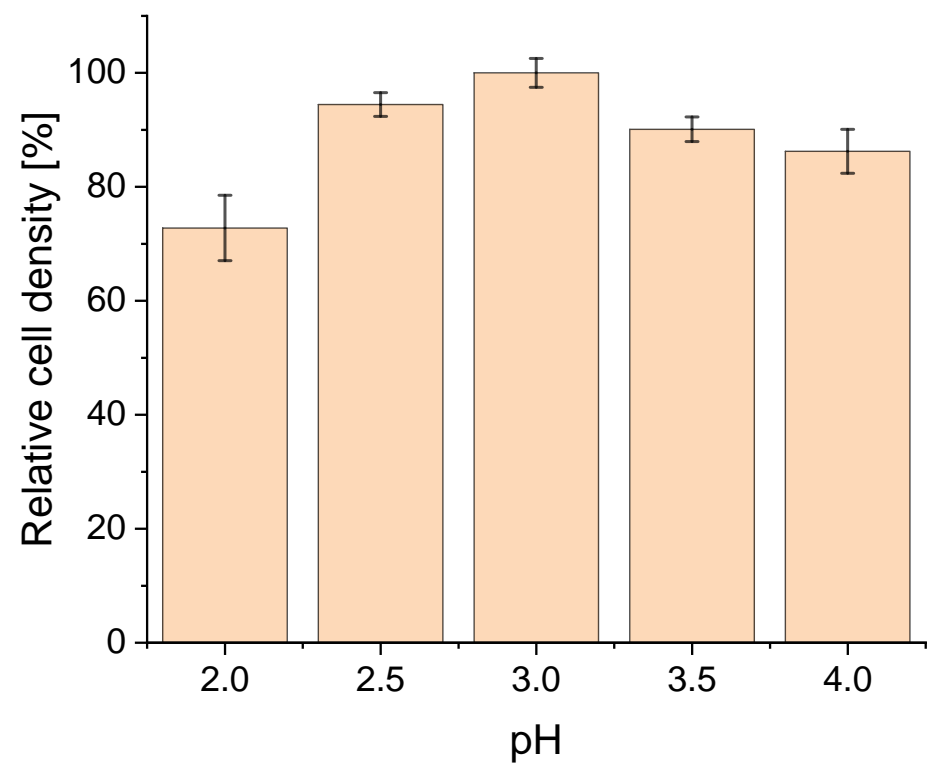

Figure 1. Relative cell density [\%] of Sulfolobus acidocaldarius in response to different $\mathrm{pH}$ values (2.0-4.0) in a chemostat cultivation at $75{ }^{\circ} \mathrm{C}$ and a set dilution rate of $0.03 \mathrm{~h}^{-1}$. Error bars indicate the standard deviation of cell density between sampling points after reaching steady state.

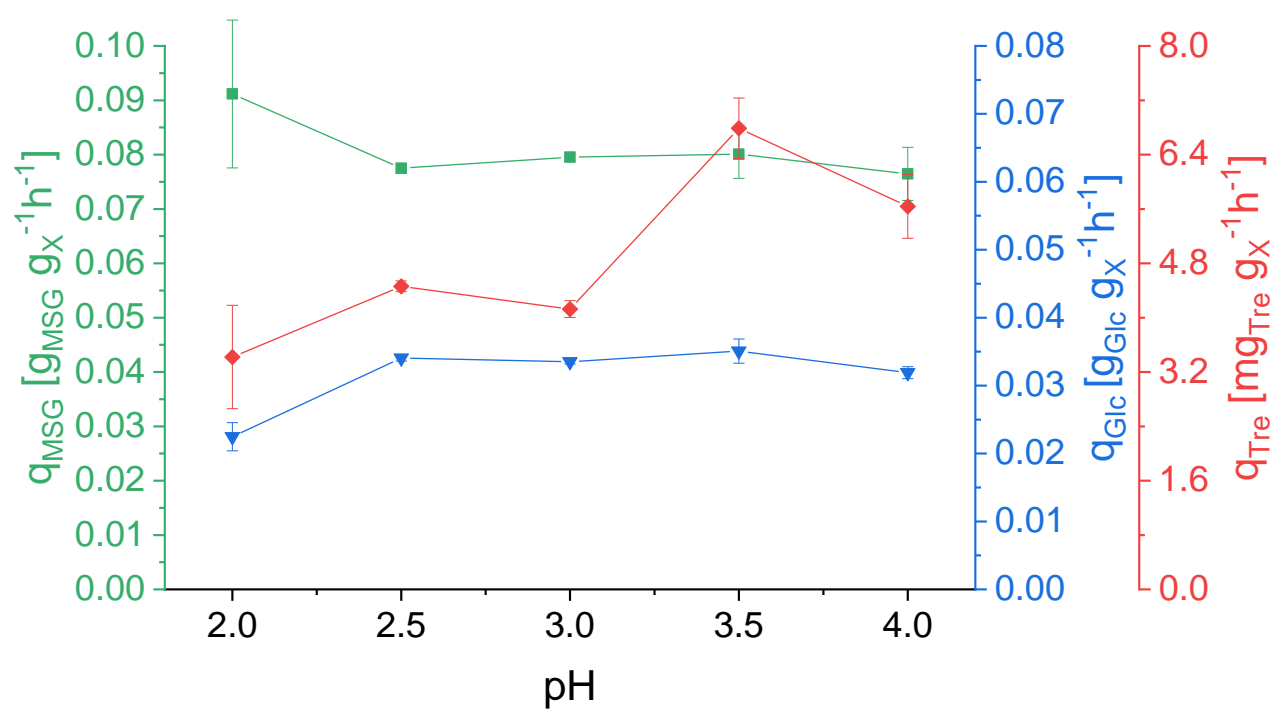

Figure 2. Specific uptake rates for L-glutamate ( $\left.\mathrm{q}_{\mathrm{MSG}}\right)$ and D-glucose $\left(\mathrm{q}_{\mathrm{Glc}}\right)$ and specific production rate of trehalose $\left(q_{T r e}\right)$ in dependence of the $\mathrm{pH}$ value. Error bars indicate the difference between the various sampling points after reaching steady state in the continuous cultivation. 


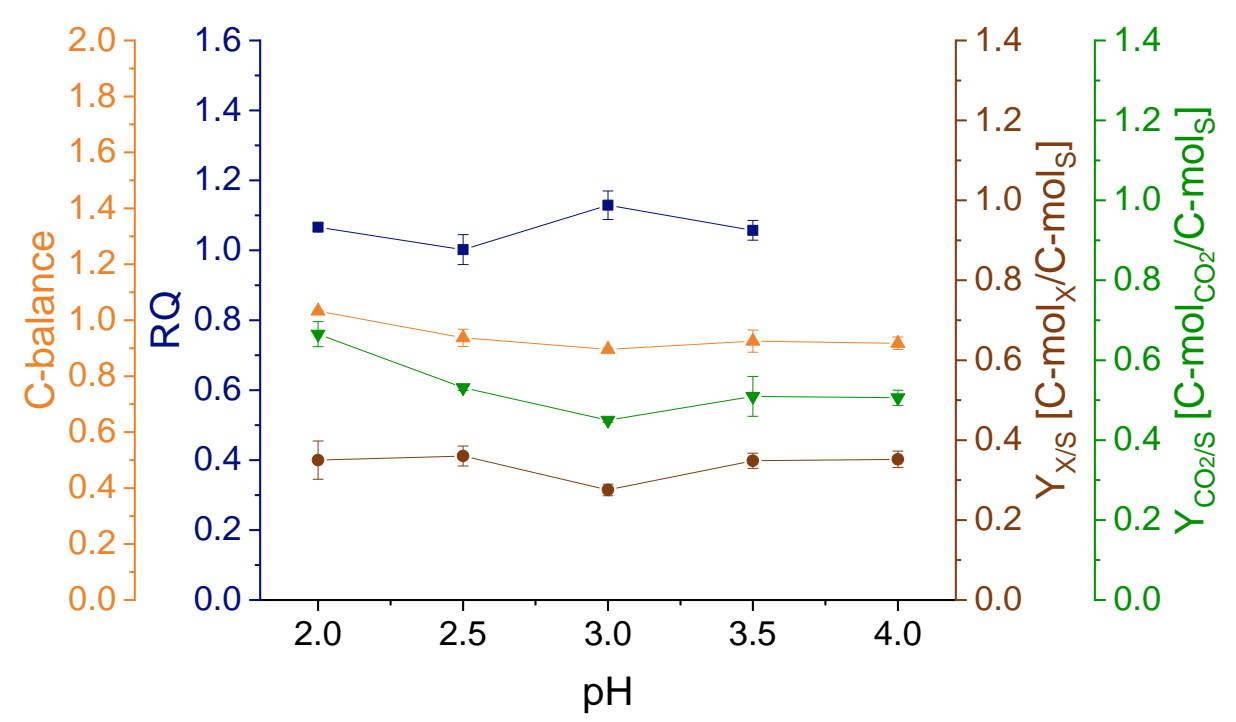

Figure 3. C-balance, respiratory quotient (RQ), biomass yield $\left(Y_{X / S}\right)$ and $\mathrm{CO}_{2}$ yield $\left(Y_{\mathrm{CO} 2 / S}\right)$ in dependence of the $\mathrm{pH}$ value. Error bars indicate the difference between the various sampling points after reaching steady state in the continuous cultivation. The RQ at $\mathrm{pH} 4.0$ could not be calculated due to a malfunction of the $\mathrm{O}_{2}$ analyzer during the cultivation.

\subsection{Effect of Dilution Rate on Strain Physiology}

For determination of $\mu_{\max }$, the optimum and critical dilution rate, the substrate affinity constants as well as the maintenance coefficient, S. acidocaldarius cultures were subjected to different dilution rates ranging from 0.010 to $0.097 \mathrm{~h}^{-1}$ at a constant $\mathrm{pH}$ of 3.0. The dilution rate was stepwise increased by increments of $\sim 0.011 \mathrm{~h}^{-1}$. D-glucose started to accumulate prior to L-glutamate while the extracellular trehalose concentration decreased as a result of increasing dilution rates (Figure 4). The cell density was the highest at a dilution rate of $0.032 \mathrm{~h}^{-1}$. However, the biomass space time yield reached its maximum at $D=0.062 \mathrm{~h}^{-1}$ with a value of $0.3 \mathrm{~g} \mathrm{~L}^{-1} \mathrm{~h}^{-1}$. A dilution rate of $0.074 \mathrm{~h}^{-1}$ led to a rapid decrease of biomass concentration in the reactor. Washout, defined as the dilution rate at which no steady state could be established, occurred between 0.084 and $0.097 \mathrm{~h}^{-1}$.

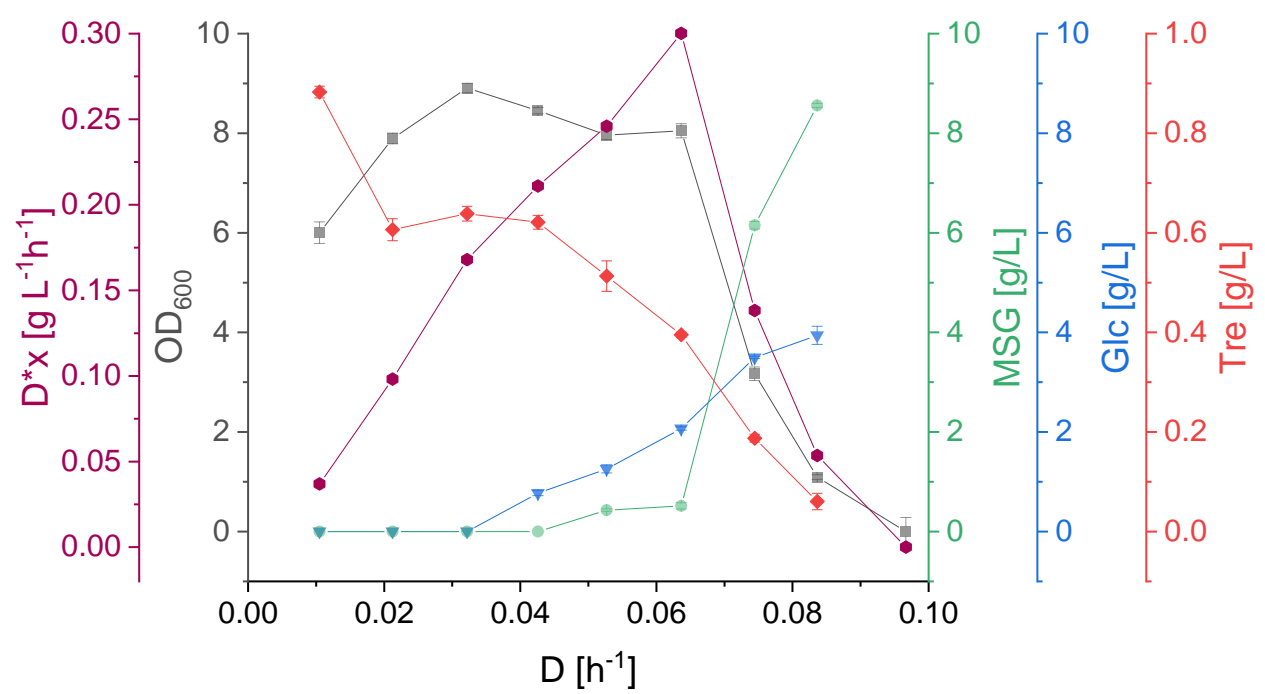

Figure 4. D-x graph: space time yield $\left(\mathrm{D}^{*} \mathrm{x}\right)$ and cell density $\left(\mathrm{OD}_{600}\right)$, monosodium glutamate (MSG), D-glucose concentration (Glc) and trehalose (Tre) concentration in the supernatant as a function of the applied dilution rate (D). Error bars indicate the difference between the various sampling points after reaching steady state in the continuous cultivation. 
Figure 5 shows the difference between the uptake rates of D-glucose and L-glutamate. While q $_{\text {MSG }}$ increased with the applied dilution rate, $\mathrm{q}_{\mathrm{Glc}}$ reached its peak at $0.053 \mathrm{~h}^{-1}$. Then $\mathrm{q}_{\mathrm{Glc}}$ decreased, indicating that the metabolic capacity had been exhausted for this substrate. The specific trehalose production was increasing in response to increasing dilution rates. This is a further indication for the role of trehalose production as part of a stress response [23]. Rising dilution rates put the cell under stress due to the growth rate approaching $\mu_{\max }$ and the organism is gradually approaching its maximal metabolic capacity $[24,25]$.

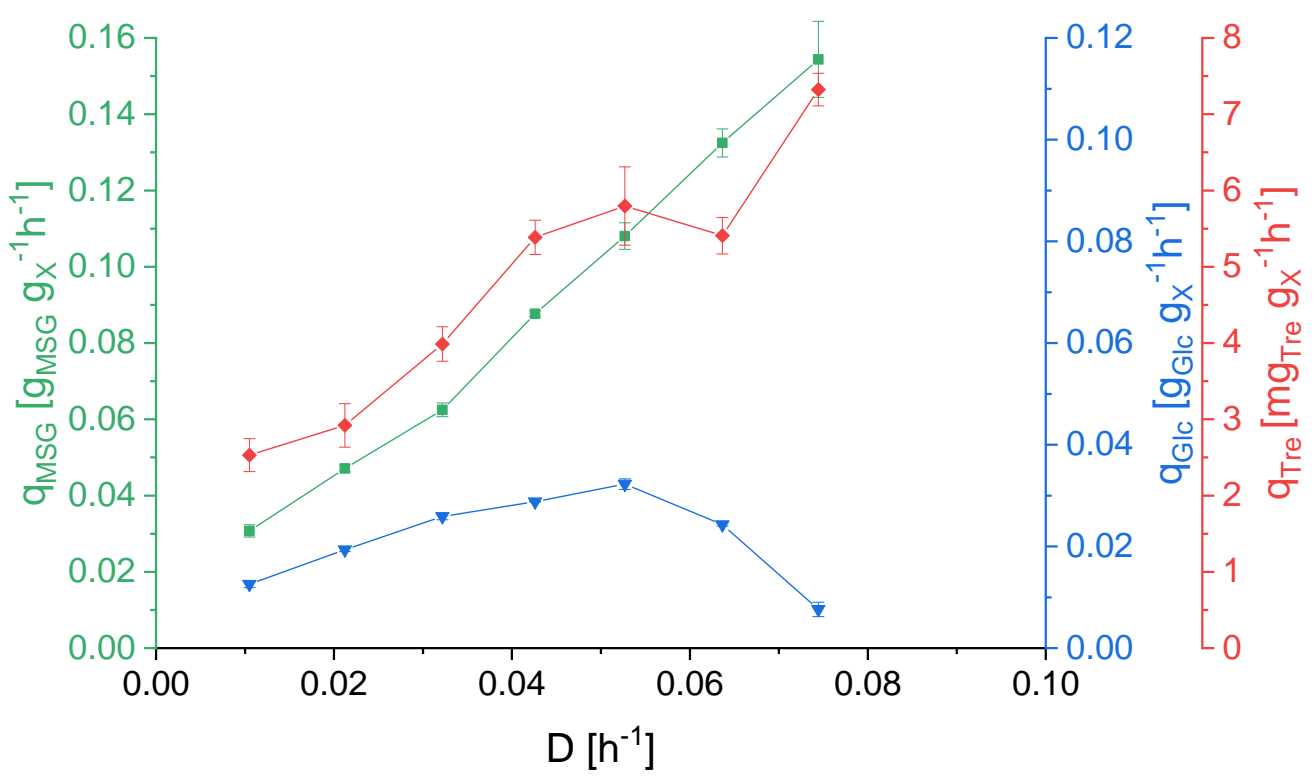

Figure 5. Specific substrate uptake rates for L-glutamate ( $\left.\mathrm{q}_{\mathrm{MSG}}\right)$ and for D-glucose $\left(\mathrm{q}_{\mathrm{Glc}}\right)$ and specific production rates of trehalose $\left(\mathrm{q}_{\text {Tre }}\right)$ in dependence of the different applied dilution rates. The specific rates at the dilution rate of $0.084 \mathrm{~h}^{-1}$ are not depicted as this dilution rate yielded highly variable rates due to it lying too close to the point of washout. Error bars indicate the difference between the various sampling points after reaching steady state in the continuous cultivation.

The course of the RQ values mirrored the $\mathrm{q}_{\mathrm{Glc}}$ trend in relation to the different applied dilution rates (Figure 6). The highest RQ of 1.18 was determined at $D=0.064 \mathrm{~h}^{-1}$ and the lowest at $D=0.010 \mathrm{~h}^{-1}$. These decreased RQ values at the lower and higher dilution rates, indicate a lower $\mathrm{CO}_{2}$ production in relation to the $\mathrm{O}_{2}$ consumption. Since $\mathrm{q}_{\mathrm{O} 2}$ varies more greatly with the dilution rates than $\mathrm{qCO}_{\mathrm{CO}}$, the main reason for the shifted RQ values is a change in the specific oxygen uptake rate, $\mathrm{q}_{\mathrm{O} 2}$. A less efficient oxygen utilization in the respiratory chain as a result of the dilution rate is a possible explanation for the increasing demand for oxygen. The $\mathrm{C}$-balance was around 1.0 until a dilution rate of $0.074 \mathrm{~h}^{-1}$. The over- and undershooting of the C-balance at dilution rates of $0.074 \mathrm{~h}^{-1}$ and higher can be interpreted as a sign for the culture reaching a non-steady state and approaching the point of washout. 


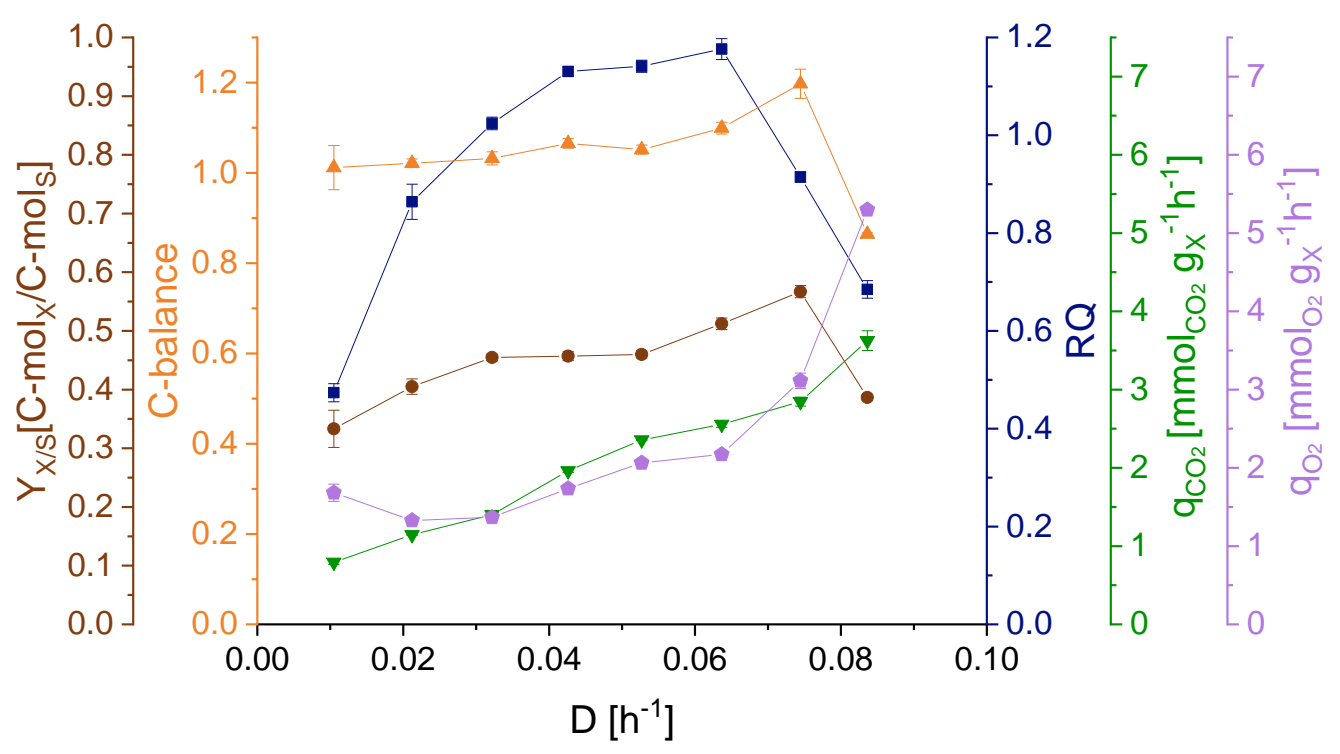

Figure 6. Biomass yield $\left(Y_{X / S}\right)$, C-balance, respiratory quotient $(\mathrm{RQ})$, specific carbon dioxide production rate ( $\left.\mathrm{q}_{\mathrm{CO} 2}\right)$ and specific oxygen consumption rate $\left(\mathrm{q}_{\mathrm{O} 2}\right)$ at each dilution rate. Error bars indicate the difference between the various sampling points after reaching steady state in the continuous cultivation.

\section{3. $K_{S}$ Values, Optimal and Critical Dilution Rate}

Based on the Monod fit of $\mu$ plotted versus the substrate concentration, the affinity constants for the used substrates, L-glutamate and D-glucose, were calculated. As shown in Figure 4, D-glucose started to accumulate at a dilution rate of $0.042 \mathrm{~h}^{-1}$ while L-glutamate did not accumulate until a dilution rate of $0.052 \mathrm{~h}^{-1}$. This is also reflected in the calculated $\mathrm{K}_{\mathrm{S}}$ values (Table 2). According to these, the affinity of $S$. acidocaldarius for D-glucose $(0.99 \mathrm{~g} / \mathrm{L})$ is 6.6 times lower than for MSG $(0.15 \mathrm{~g} / \mathrm{L})$. The resulting theoretical $\mu_{\max }$, determined via the Monod fit, also differed for the two substrates, $0.077 \mathrm{~h}^{-1}$ for MSG and $0.095 \mathrm{~h}^{-1}$ for D-glucose. Based on the exponential increase of the $\mathrm{CO}_{2}$ concentration in the exhaust gas during the batch phase at the beginning of the cultivation, $\mu_{\max }$ was determined as $0.097 \mathrm{~h}^{-1}$.

Table 2. Affinity constants $\left(\mathrm{K}_{\mathrm{S}}\right)$ and maximum growth rates $\left(\mu_{\max }\right)$ for D-glucose and monosodium glutamate, obtained by fitting the growth rates versus the substrates concentration in the supernatant to the Monod equation with SigmaPlot. With the obtained values, the optimal $\left(\mathrm{D}_{\text {opt }}\right)$ and critical dilution rate $\left(\mathrm{D}_{\text {crit }}\right)$ were calculated.

\begin{tabular}{ccc}
\hline Parameters & D-Glucose & Monosodium Glutamate (MSG) \\
\hline$\mu_{\text {max }}\left[\mathrm{h}^{-1}\right]$ & $0.095 \pm 0.004$ & $0.077 \pm 0.003$ \\
$\mathrm{~K}_{\mathrm{S}}[\mathrm{g} / \mathrm{L}]$ & $0.99 \pm 0.13$ & $0.15 \pm 0.04$ \\
$\mathrm{D}_{\text {opt }}\left[\mathrm{h}^{-1}\right]$ & 0.055 & 0.068 \\
$\mathrm{D}_{\text {crit }}\left[\mathrm{h}^{-1}\right]$ & 0.078 & 0.077 \\
\hline
\end{tabular}

The optimal dilution rate calculated in this study is different in depending on the different substrate uptakes (Table 2). A lower $D_{\text {opt }}$ of $0.055 \mathrm{~h}^{-1}$ is postulated based on the utilization of D-glucose. However, for the main substrate L-glutamate an optimal dilution rate of $0.068 \mathrm{~h}^{-1}$ is calculated, which is supported by the $\mathrm{D}^{*} \mathrm{x}$ diagram (Figure 4 ). The considerable difference in $\mathrm{K}_{\mathrm{S}}$ values for the substrates causes the divergence of the actual $\mathrm{D}_{\text {opt }}$ to the one presumed based on D-glucose, while the uptake of L-glutamate increased the optimal dilution rate. The calculated $D_{\text {crit }}$ of around $0.077 \mathrm{~h}^{-1}$ after which washout should occur is slightly lower compared to the obtained experimental data $\left(D=0.084 \mathrm{~h}^{-1}\right.$, Figure 4). 


\subsection{Maintenance}

Maintenance respiration in thermoacidophiles is assumed to be relatively high [26], due to the need for retaining a near neutral cytosolic $\mathrm{pH}$ of 6.5 [27] as well as for repairing DNA and protein damage as a result of the high temperature [28] thereby possibly draining the supply of carbon sources available for biomass growth. Therefore, to further characterize $S$. acidocaldarius, its maintenance coefficient was calculated by plotting $\mathrm{q}_{S}$ $\left(\mathrm{q}_{\mathrm{Glc}}+\mathrm{q}_{\mathrm{MSG}}\right)$ versus growth rate. The maintenance coefficient for the total substrate was determined according to Equation (8), as well as the true biomass yield (the biomass yield per substrate used solely for growth). For this calculation, just the values of the dilution rates between 0.010 and $0.064 \mathrm{~h}^{-1}$ were considered, since higher dilution rate showed a flattening of the curve as the $\mathrm{q}_{S}$ values differed only marginally. Thereby, a true biomass yield of $0.42 \mathrm{~g}(X) / \mathrm{g}(S)$ was determined. The calculated maintenance requirement, $\mathrm{m}_{\mathrm{S}}$, of $0.017 \mathrm{~g}(S) \mathrm{g}(X)^{-1} \mathrm{~h}^{-1}$ for $S$. acidocaldarius for the mixed substrate feed with D-glucose and L-glutamate is surprisingly low, since Korz et al. postulated the maintenance coefficient in Escherichia coli to be $0.025 \mathrm{gS} / \mathrm{gX} / \mathrm{h}$ cultivated in D-glucose or glycerol [29]. Nevertheless, in relative terms the ratio of $\mathrm{m}_{S}$ to the observed total $\mathrm{q}_{S}$ is around $10 \%$ at a dilution rate of $0.075 \mathrm{~h}^{-1}$ and increases with decreasing dilution rates to $39 \%$ at $0.010 \mathrm{~h}^{-1}$. Even though similar values of maintenance coefficients were observed in other organisms and the biomass yield for D-glucose is also comparable to E. coli [30], the possible $\mathrm{q}_{S}$ values in bacteria is higher by up to $3.42-12.8$ fold [30]. Hence, in that perspective the ratio maintenance coefficient to substrate uptake rates is much higher in this extremophilic organism. Studies in other bacteria showed a high variability in maintenance coefficients within the same species. This variation, in addition to differently specified coefficient units, impedes comparison with other species. Nevertheless, a trend towards higher maintenance coefficients was observed under anaerobic cultivation conditions [31,32]. Unfortunately, no comparative results for maintenance coefficient in Archaea was found.

\section{Discussion}

While there is broad consensus on the optimal growth temperature of S. acidocaldarius being at $75{ }^{\circ} \mathrm{C}[7-10,33]$ the described optimal cultivation $\mathrm{pH}$ still varies [5-10]. Our study determined a $\mathrm{pH}$ optimum of 3.0 in regards to the cell density during continuous cultivation (Figure 2), contradicting the recent publication by Cobban et al. [11], in which higher biomass yields were observed at $\mathrm{pH} 2.0$ and 4.0 compared to $\mathrm{pH}$ 3.0. A possible reason for the differences could be the used cultivation temperature for their experiments of $70{ }^{\circ} \mathrm{C}$ and that cultivations were performed in batch mode using a different medium.

The applied $\mathrm{pH}$ influenced the specific glucose uptake rate and the specific trehalose production rate (Figure 3). According to the obtained data, higher $\mathrm{pH}$ triggered trehalose production while lower $\mathrm{pH}$ had no effect. Koerdt et al. [34] showed increasing biofilm formation with increasing $\mathrm{pHs}$ as well as upregulated sugar transport for the formation of the biofilm. In the present study, specific trehalose production was upregulated at higher pHs, possibly going hand-in-hand with the observed increased biofilm formation at higher $\mathrm{pH}$ values by Koerdt et al.

The substrate uptake rates (Figure 5) are in accordance with the obtained $\mathrm{K}_{\mathrm{s}}$ values (Table 2). D-glucose, like other saccharides, is transported into the cell via an ATP binding cassettes $(\mathrm{ABC})$ transporter $[35,36]$. The transporter for L-glutamate has not been identified yet. Until now, $A B C$ transporters were only found to be responsible for di- and oligopeptide uptake in Saccharolobus solfataricus (Sulfolobus solfataricus) and Sulfurisphaera tokodaii (Sulfolobus tokodaii) [35]. However, these are all close relatives of S. acidocaldarius. Amino acids have also been shown to be transported into organisms by facilitated diffusion [37]. Despite the organism's preference of MSG over D-glucose, the presence of the latter is still beneficial. The specific uptake rate increases until $D=0.053 \mathrm{~h}^{-1}$, confirming the organism's capacity for metabolizing D-glucose and MSG concomitantly.

Upon changing dilution rates, the respiratory behavior, as shown by the RQ values, as well as the calculated C-balances (Figure 6) indicate a shift in the carbon flow. 
Additionally, the elevated oxygen consumption at low and high dilution rates further propose an impairment in the respiratory chain, implying a higher $\mathrm{O}_{2}$ need for substrate metabolization.

With the obtained data a range of 0.077 to $0.097 \mathrm{~h}^{-1}$ for $\mu_{\max }$ was identified. According to the exponential increase in the batch phase $\mu_{\max }$ is $0.097 \mathrm{~h}^{-1}$. In the applied chemostat cultivation $\mu_{\max }$ lies between 0.084 and $0.097 \mathrm{~h}^{-1}$. Based on the Monod fit for each substrate, $\mu_{\max }$ varies significantly between $0.077 \mathrm{~h}^{-1}$ for MSG and $0.095 \mathrm{~h}^{-1}$ for D-glucose. The overall range of obtained $\mu_{\max }$ is in accordance with data obtained in shake flask cultivation within the genus Sulfolobus spp. [22,38].

The characterization of S. acidocaldarius in a continuous bioreactor environment and determination of the relationship between $\mathrm{pH}$, substrate uptake and trehalose production rate showed indications for distinctive stress responses at extreme $\mathrm{pH}$ values and dilution rates expressed as low $R Q$ values, increased trehalose production and decreased specific glucose uptake rates. This study demonstrates the value of CSTR setups for fast and reliable generation of physiological parameters in a highly reproducible environment. As an outlook, the methodology described in this work can be used for medium optimization based on substrate affinity, control of biomass and metabolite production and optimization of time-space-yields in production processes in industrial settings, as well as the determination of operation windows of process conditions where robust cultivation of S. acidocaldarius is possible. Overall, with this study we could bring novel insight in the physiology of S. acidocaldarius under steady-state conditions and provide a basis for further bioprocess development, monitoring and control.

\section{Conclusions}

In this study, physiological characterization in a controlled chemostat cultivation using a modified VD Medium at a constant temperature of $75^{\circ} \mathrm{C}$ was conducted. The $\mathrm{pH}$ optimum was confirmed to be 3.0. The affinity constants of the used carbon sources, D-glucose and MSG was determined. The specific glucose uptake rates in response to the dilution rates imply a possible overflow metabolism in which the substrate is incompletely oxidized despite the availability of oxygen which however has to be further investigated for possible verification. The maximum growth rate was determined to be $0.097 \mathrm{~h}^{-1}$. Respiratory behavior and trehalose production changed as a response to the different $\mathrm{pH}$ and dilution rate, indicating a stress response of the organism. All in all, it was shown that controlled cultivation conditions employing S. acidocaldarius are possible and beneficiary for further research topics of this crenarchaeal model organism and represent a solid foundation for further bioprocess development.

Supplementary Materials: The following are available online at https://www.mdpi.com/article/ 10.3390/ijerph18115532/s1, Figure S1: Correlation between dry cell weight (DCW) and $\mathrm{OD}_{600}$ of Sulfolobus acidocaldarius.

Author Contributions: Conceptualization, K.R., D.J.W., O.S. and J.Q.; investigation, K.R.; writingoriginal draft preparation, K.R.; writing - review and editing, J.Q., D.J.W. and O.S.; visualization, K.R.; supervision, J.Q.; project administration, D.J.W.; funding acquisition, O.S. All authors have read and agreed to the published version of the manuscript.

Funding: J.Q. acknowledges funding from the Austrian Science Fund (FWF) via the project " $\mathrm{CO}_{2}$ fixation in extreme conditions" (Project Nr.: I 4508). Additionally, the authors acknowledge the TU Wien Bibliothek for financial support through its Open Access Funding Program.

Institutional Review Board Statement: Not applicable.

Informed Consent Statement: Not applicable.

Acknowledgments: Open Access Funding by the Austrian Science Fund (FWF).

Conflicts of Interest: The authors declare no conflict of interest. 


\section{References}

1. Chen, L.; Brügger, K.; Skovgaard, M.; Redder, P.; She, Q.; Torarinsson, E.; Greve, B.; Awayez, M.; Zibat, A.; Klenk, H.-P.; et al. The Genome of Sulfolobus Acidocaldarius, a Model Organism of the Crenarchaeota. J. Bacteriol. 2005, 187, 4992-4999. [CrossRef]

2. Wagner, M.; van Wolferen, M.; Wagner, A.; Lassak, K.; Meyer, B.H.; Reimann, J.; Albers, S.-V. Versatile Genetic Tool Box for the Crenarchaeote Sulfolobus Acidocaldarius. Front. Microbiol. 2012, 3. [CrossRef]

3. Gudbergsdottir, S.; Deng, L.; Chen, Z.; Jensen, J.V.K.; Jensen, L.R.; She, Q.; Garrett, R.A. Dynamic Properties of the Sulfolobus CRISPR/Cas and CRISPR/Cmr Systems When Challenged with Vector-Borne Viral and Plasmid Genes and Protospacers. Mol. Microbiol. 2011, 79, 35-49. [CrossRef]

4. Grogan, D.W. Phenotypic Characterization of the Archaebacterial Genus Sulfolobus: Comparison of Five Wild-Type Strains. J Bacteriol. 1989, 171, 6710-6719. [CrossRef] [PubMed]

5. Zhou, A.; Weber, Y.; Chiu, B.K.; Elling, F.J.; Cobban, A.B.; Pearson, A.; Leavitt, W.D. Energy Flux Controls Tetraether Lipid Cyclization in Sulfolobus Acidocaldarius. Environ. Microbiol. 2020, 22, 343-353. [CrossRef] [PubMed]

6. Buetti-Dinh, A.; Dethlefsen, O.; Friedman, R.; Dopson, M. Transcriptomic Analysis Reveals How a Lack of Potassium Ions Increases Sulfolobus Acidocaldarius Sensitivity to PH Changes. Microbiology 2016, 162, 1422-1434. [CrossRef]

7. Quehenberger, J.; Pittenauer, E.; Allmaier, G.; Spadiut, O. The Influence of the Specific Growth Rate on the Lipid Composition of Sulfolobus Acidocaldarius. Extremophiles 2020. [CrossRef] [PubMed]

8. Zeng, Z.; Liu, X.-L.; Wei, J.H.; Summons, R.E.; Welander, P.V. Calditol-Linked Membrane Lipids Are Required for Acid Tolerance in Sulfolobus Acidocaldarius. Proc. Natl. Acad. Sci. USA 2018, 115. [CrossRef] [PubMed]

9. Bischof, L.F.; Haurat, M.F.; Hoffmann, L.; Albersmeier, A.; Wolf, J.; Neu, A.; Pham, T.K.; Albaum, S.A.; Jakobi, T.; Schouten, S.; et al. Early Response of Sulfolobus Acidocaldarius to Nutrient Limitation. Front. Microbiol. 2019, 9. [CrossRef]

10. Guan, Z.; Delago, A.; Nußbaum, P.; Meyer, B.; Albers, S.-V.; Eichler, J. Gene Deletions Leading to a Reduction in the Number of Cyclopentane Rings in Sulfolobus Acidocaldarius Tetraether Lipids. Fems Microbiol. Lett. 2018, 365. [CrossRef]

11. Cobban, A.; Zhang, Y.; Zhou, A.; Weber, Y.; Elling, F.J.; Pearson, A.; Leavitt, W.D. Multiple Environmental Parameters Impact Lipid Cyclization in Sulfolobus Acidocaldarius. Environ. Microbiol. 2020, 22, 4046-4056. [CrossRef] [PubMed]

12. Garcia-Ochoa, F.; Santos, V.E.; Gomez, E. 2.15-Stirred Tank Bioreactors. In Comprehensive Biotechnology, 2nd ed.; Moo-Young, M., Ed.; Academic Press: Burlington, NJ, USA, 2011; pp. 179-198. ISBN 978-0-08-088504-9.

13. Brock, T.D.; Mosser, J.L. Rate of Sulfuric-Acid Production in Yellowstone National Park. Gsa Bull. 1975, 86, 194-198. [CrossRef]

14. Spangler, L.E.; Susong, D.D. Use of Dye Tracing to Determine Ground-Water Movement to Mammoth Crystal Springs, Sylvan Pass Area, Yellowstone National Park, Wyoming; Scientific Investigations Report; U.S. Geological Survey: Reston, VA, USA, 2006; Volume 2006-5126, p. 19.

15. McMillan, N.; Larson, P.; Fairley, J.; Mulvaney-Norris, J.; Lindsey, C.R. Direct Measurement of Advective Heat Flux from Several Yellowstone Hot Springs, Wyoming, USA. Geosphere 2018. [CrossRef]

16. Žnidaršič-Plazl, P.; Plazl, I. 2.21-Microbioreactors. In Comprehensive Biotechnology, 2nd ed.; Moo-Young, M., Ed.; Academic Press: Burlington, NJ, USA, 2011; pp. 289-301. ISBN 978-0-08-088504-9.

17. Weusthuis, R.A.; Pronk, J.T.; van den Broek, P.J.; van Dijken, J.P. Chemostat Cultivation as a Tool for Studies on Sugar Transport in Yeasts. Microbiol Rev 1994, 58, 616-630. [CrossRef] [PubMed]

18. Dunham, M.J.; Kerr, E.O.; Miller, A.W.; Payen, C. Chemostat Culture for Yeast Physiology and Experimental Evolution. Cold Spring Harb. Protoc. 2017, 2017. [CrossRef] [PubMed]

19. Lin, H.; Bennett, G.N.; San, K.-Y. Chemostat Culture Characterization of Escherichia Coli Mutant Strains Metabolically Engineered for Aerobic Succinate Production: A Study of the Modified Metabolic Network Based on Metabolite Profile, Enzyme Activity, and Gene Expression Profile. Metab. Eng. 2005, 7, 337-352. [CrossRef] [PubMed]

20. Patel, H.; Kerndt, C.C.; Bhardwaj, A. Physiology, Respiratory Quotient. In StatPearls; StatPearls Publishing: Treasure Island, FL, USA, 2020.

21. Elbein, A.D.; Pan, Y.T.; Pastuszak, I.; Carroll, D. New Insights on Trehalose: A Multifunctional Molecule. Glycobiology 2003, 13, 17R-27R. [CrossRef]

22. Quehenberger, J.; Albersmeier, A.; Glatzel, H.; Hackl, M.; Kalinowski, J.; Spadiut, O. A Defined Cultivation Medium for Sulfolobus Acidocaldarius. J. Biotechnol. 2019, 301, 56-67. [CrossRef]

23. Stracke, C.; Meyer, B.H.; Hagemann, A.; Jo, E.; Lee, A.; Albers, S.-V.; Cha, J.; Bräsen, C.; Siebers, B. Salt Stress Response of Sulfolobus Acidocaldarius Involves Complex Trehalose Metabolism Utilizing a Novel Trehalose-6-Phosphate Synthase (TPS)/Trehalose-6Phosphate Phosphatase (TPP) Pathway. Appl. Environ. Microbiol. 2020, 86. [CrossRef]

24. Vemuri, G.N.; Altman, E.; Sangurdekar, D.P.; Khodursky, A.B.; Eiteman, M.A. Overflow Metabolism in Escherichia Coli during Steady-State Growth: Transcriptional Regulation and Effect of the Redox Ratio. Appl. Environ. Microbiol. 2006, 72, 3653-3661. [CrossRef]

25. Valgepea, K.; Adamberg, K.; Nahku, R.; Lahtvee, P.-J.; Arike, L.; Vilu, R. Systems Biology Approach Reveals That Overflow Metabolism of Acetate in Escherichia Coli Is Triggered by Carbon Catabolite Repression of Acetyl-CoA Synthetase. BMC Syst. Biol. 2010, 4, 166. [CrossRef]

26. Valentine, D.L. Adaptations to Energy Stress Dictate the Ecology and Evolution of the Archaea. Nat. Rev. Microbiol. 2007, 5,316-323. [CrossRef] [PubMed] 
27. Brock, T.D.; Brock, K.M.; Belly, R.T.; Weiss, R.L. Sulfolobus: A New Genus of Sulfur-Oxidizing Bacteria Living at Low PH and High Temperature. Arch. Mikrobiol. 1972, 84, 54-68. [CrossRef] [PubMed]

28. Granata, V.; Graziano, G.; Ruggiero, A.; Raimo, G.; Masullo, M.; Arcari, P.; Vitagliano, L.; Zagari, A. Stability against Temperature of Sulfolobus Solfataricus Elongation Factor $1 \alpha$, a Multi-Domain Protein. Biochim. Biophys. Acta (Bba) Proteins Proteom. 2008, 1784, 573-581. [CrossRef] [PubMed]

29. Korz, D.J.; Rinas, U.; Hellmuth, K.; Sanders, E.A.; Deckwer, W.-D. Simple Fed-Batch Technique for High Cell Density Cultivation of Escherichia Coli. J. Biotechnol. 1995, 39, 59-65. [CrossRef]

30. Shiloach, J.; Fass, R. Growing E. Coli to High Cell Density-A Historical Perspective on Method Development. Biotechnol. Adv. 2005, 23, 345-357. [CrossRef] [PubMed]

31. Singh, R.; Tevatia, R.; White, D.; Demirel, Y.; Blum, P. Comparative Kinetic Modeling of Growth and Molecular Hydrogen Overproduction by Engineered Strains of Thermotoga Maritima. Int. J. Hydrog. Energy 2019, 44, 7125-7136. [CrossRef]

32. Pirt, S.J. The Maintenance Energy of Bacteria in Growing Cultures. Proc. R. Soc. Lond. Ser. B Biol. Sci. 1965, 163, $224-231$.

33. Vetter, A.M.; Helmecke, J.; Schomburg, D.; Neumann-Schaal, M. The Impact of Pyroglutamate: Sulfolobus Acidocaldarius Has a Growth Advantage over Saccharolobus Solfataricus in Glutamate-Containing Media. Archaea 2019, 2019, 3208051. [CrossRef]

34. Koerdt, A.; Gödeke, J.; Berger, J.; Thormann, K.M.; Albers, S.-V. Crenarchaeal Biofilm Formation under Extreme Conditions. PLOS ONE 2010, 5, e14104. [CrossRef]

35. Albers, S.-V.; Koning, S.; Konings, W.; Driessen, A. Insights into ABC Transport in Archaea. J. Bioenerg. Biomembr. 2004, $36,5-15$. [CrossRef] [PubMed]

36. Wagner, M.; Shen, L.; Albersmeier, A.; van der Kolk, N.; Kim, S.; Cha, J.; Bräsen, C.; Kalinowski, J.; Siebers, B.; Albers, S.-V. Sulfolobus Acidocaldarius Transports Pentoses via a Carbohydrate Uptake Transporter 2 (CUT2)-Type ABC Transporter and Metabolizes Them through the Aldolase-Independent Weimberg Pathway. Appl. Environ. Microbiol. 2018, 84. [CrossRef] [PubMed]

37. Cooper, G.M. Transport of Small Molecules. In The Cell: A Molecular Approach, 2nd ed.; Sinauer Associates: Sunderland, MA, USA, 2000.

38. McCarthy, S.; Johnson, T.; Pavlik, B.L.; Payne, S.; Schackwitz, W.; Martin, J.; Lipzen, A.; Keffeler, E.; Blum, P. Expanding the Limits of Thermoacidophily in the Archaeon Sulfolobus Solfataricus by Adaptive Evolution. Appl. Environ. Microbiol. 2016, 82. [CrossRef] [PubMed] 